\title{
SIGNIFICANCE OF THE RADIOGRAPHIC PARAMETERS IN THE DIAGNOSIS AND TREATMENT OF A BONY IMPINGEMENT OF THE ELBOW
}

\author{
POMEN RADIOGRAFSKIH PARAMETROV V DIAGNOZI IN PRI \\ ZDRAVLJENJU KOSTNE UTESNITVE KOMOLCA
}

\author{
Uroš Meglič, Oskar Zupanc \\ Department of Orthopaedic Surgery, University Medical Centre Ljubljana, Zaloška cesta 9, 1000 Ljubljana, Slovenia \\ Prejem rokopisa - received: 2018-10-28; sprejem za objavo - accepted for publication: 2019-05-17
}

doi:10.17222/mit.2018.232

\begin{abstract}
An elbow's bony impingement is an early x-ray sign of a degenerative process in the elbow joint. Formatted osteophytes in the anterior and posterior compartment of the elbow change the elbow geometry and cause an early deficit in the elbow's range of motion. Because it has a devastating impact on athletes and manual laborers, it has to be recognized and treated early. To do so, a reliable diagnostic method is a necessity. In our study we introduced and tested the radiographic parameters that can be used when diagnosing, pre-operative planning and post-operative evaluating the bony impingement of an elbow.

Keywords: elbow, impingement, osteoarthrosis, radiographic parameters
\end{abstract}

Kostna utesnitev komolca je znak začetne degenerativne bolezni komolca. Kostne naplastitve v sprednjem in zadnjem delu komolca spremenijo geometrijo komolca in povzročijo zgodnje zmanjšanje gibljivosti. Zaradi povzročitve hudih omejitev pri športnikih in fizičnih delavcih, sta diagnostika in zdravljenje nujni v zgodnji fazi bolezni. Za to so potrebni zanesljivi diagnostični kazalci. V naši raziskavi smo opredelili in testirali radiološke kazalce, ki jih lahko uporabimo pri diagnostiki, predoperativnem planiranju in pooperativni oceni kostne utesnitve komolca.

Ključne besede: komolec, utesnitev, osteoartroza, radiološki parametri

\section{INTRODUCTION}

The main functions of the elbow are to position the hand in space and to act as a stabilizer for actions such as carrying, throwing, pushing, pulling, and lifting. ${ }^{1}$ The normal arc of motion of the elbow is from 0 degrees of flexion to 145 degrees of flexion. In order to accomplish its function, the elbow needs a full or almost full range of motion (ROM). ${ }^{2}$ Recent biomechanical studies concluded that an arc of motion between 30 degrees and 130 degrees is enough to achieve $90 \%$ of the activities of daily living. ${ }^{1}$ However, even a smaller loss of flexion or extension of the elbow of the dominant hand for an athlete or physical worker can be devastating and has an impact on its function. ${ }^{3}$ Thus, it has to be recognized in the early stages of degenerative elbow disease. Early elbow degenerative changes are caused by several etiological factors, mostly due to physical labor or overuse in sports activities. The bony impingement of the elbow is one of the earliest $\mathrm{x}$-ray signs of the elbow degenerative disease that cause symptoms like pain, skipping, pinching during elbow moving and finally reduced elbow ROM, especially flexion. ${ }^{4}$ It can occur between an enlarged coronoid process and obliterated coronoid fossa or enlarged olecranon tip and olecranon fossa due to

*Corresponding author's e-mail:

uros.meglic@kclj.si osteophyte formation. First, in the elbow's final flexion or extension soft tissues (i.e., synovia, joint capsule, periost, cartilage) are compressed within the joint. ${ }^{5}$ If compressive forces are excessive or too repetitive, damage and inflammation of these tissues may occur. Inflammation on these sites of the elbow can promote osteoblastic activity and the formation of bony osteophytes. ${ }^{6}$

In symptomatic patients, first the conservative treatment and rehabilitation are started, but this can last for a long period of time, and often with sub-optimal clinical results. ${ }^{4}$ If a conservative treatment is not successful to maintain and improve the elbow's function, arthroscopic debridement and resection of the osteophytes are needed. ${ }^{7}$ For doing so, a reliable diagnostic method is a necessity. In the literature there is no description of the standardized radiographic parameters for diagnosing bony elbow impingement. In our study we introduced and tested radiographic parameters that can be used in diagnosing, pre-operative planning and post-operative evaluating of a bony impingement of the elbow.

\section{MATERIALS AND METHODS}

In our study group we included 31 patients with clinically significant bony elbow impingement recruited for operative treatment to the Department of Orthopaedic 
Surgery, University Medical Centre Ljubljana. As a control group we included 31 patients, treated at the same department because of other elbow pathologies (epicondylitis, ulnar neuritis etc.), but with a normal range of motion and no signs of clinical elbow impingement. Patients with a clinical history of previous injury, upper extremity abnormality and severe arthrosis were excluded from the study. A standard clinical examination was performed. Standard antero-posterior and lateral $\mathrm{x}$-ray views were obtained. Unsatisfactory films were repeated in order to maintain consistency. Radiographic measurements were made prior to any further treatment. The Mayo elbow score was used to evaluate the clinical significance of the elbow disease in both groups. ${ }^{8}$

Besides the $\mathrm{x}$-ray signs of bony impingement, bone osteophytes were confirmed with arthroscopy during the arthroscopic debridement.

Radiographic measurements of the two impingement arcs were obtained prior to the operative treatment. The impingement arcs were measured on standard lateral $\mathrm{X}$-ray images by first drawing the largest standard circle that would best fill the greater sigmoid notch. The center of the circle represented the center of rotation. Then the ulnar bone direction line and its parallel through the center of rotation were drawn. The angle between the centralized ulnar direction line and the line between the center of rotation and the tip of the coronoid process is named the Anterior Impingement (AI) arc. The angle between the centralized ulnar direction line and the line between the center of rotation and the tip of the olecranon process is named the Posterior Impingement (PI) arc. An example of AI and PI arc measurements on a lateral elbow X-ray is demonstrated in Figure 1. These parameters were then used for diagnosing the elbow's bony impingement and in the study group for preoperative planning and post-operative evaluation.

Microsoft Excel 2016 and SPSS version 20 were used for the analyses. The Student t test was used for group comparisons when normality was accepted and the Mann-Whitney U test was used when normality was rejected. The Chi-square test was used for group comparisons of two categorical variables. A P value of $<0.05$ was considered statistically significant.

The National Medical Ethics Committee's approval was obtained for this study.

\section{RESULTS}

All the patients included in the study and the control group were analyzed (100\%). Table $\mathbf{1}$ summarizes the patients' characteristics. During a pre-operative evaluation the clinical examination showed a statistically significant difference in the ROM between the groups. The study group presents with a mean $115^{\circ}$ of flexion and $19^{\circ}$ of extension deficit, which is considered pathologic according to the literature. In the control group the ROM was normal, with full flexion and extension. In the study group the impingement arcs on lateral radiographs were statistically significantly higher compared to the control group. In the study group the $\mathrm{AI}$ arc is $44 \pm 7^{\circ}$, the PI arc is $172 \pm 10^{\circ}$. In the control group the AI arc is $20 \pm 4^{\circ}$, the PI arc ${ }^{\circ}$. Table 3 summarizes the measurements in the study group comparing the measurements before and after the operation. During the post-operative evaluation there was no statistically significant difference in the ROM and impingement arcs on the postoperative radiographs between the groups.

\section{DISCUSSION}

Elbow bony impingement is an early x-ray sign of a degenerative process in the elbow joint. ${ }^{9}$ Formatted osteophytes in the anterior and posterior compartments of the elbow change the elbow's geometry and cause early flexion or extension deficit of the elbow movement. It is an important disability factor in patients who overuse their elbow, such as in professional overhead athletes and manual laborers ${ }^{3}$ and must be recognized and treated early. ${ }^{4}$

In order to establish the treatment algorithms and evaluate the outcomes, common and reliable methods of measurement and assessment are necessary. In our research we established radiographic criteria that can be used for diagnosing and evaluating the bony impingement of the elbow. All of the elbows in our study group demonstrated a significantly higher value of the AI and PI arcs compared to the control group. There is no overlapping of the AI arc and the PI arc values between the groups. In our opinion this gives us valuable criteria for diagnosing anterior and posterior elbow impingements. In all cases the bony impingement was confirmed during arthroscopic debridement and other possible causes were clinically excluded. Thus, the AI arc is utilized to assess the bony spurs formatted on the tip of the coronoid process, and the PI arc can be used to assess the bony osteophytes formatted on the olecranon process. Also, a significant decrease of the AI and PI arc values in the control group after surgery was observed and supported by a clinical improvement of the patients. The decreased values of the AI and PI arcs are in the range of those measured in the control group, thus further increasing the value of both criteria. With these results we can confirm the establishment of a set of radiographic parameters that can be used for the investigation of a bony impingement of the elbow.

In the literature several conditions have been described regarding elbow overuse in professional athletes. K. P.Valkering et al. referred to posterolateral elbow impingement in boxers as boxers elbow; ${ }^{10} \mathrm{~S}$. Tyrdal and R. Bahr described repeated hyperextension trauma, called as handball goalies elbow ${ }^{11}$; valgus extension overload syndrome in overhead-throwing athletes was described by F.S. Chen et al., ${ }^{12}$ but none of those researches gives us any common and reliable methods of measurement. Some information exists describing the 
normal radiographic anatomy of the elbow. ${ }^{13}$ Previous literature focuses primarily on fracture outcomes, ${ }^{14}$ ossification patterns ${ }^{15}$ and gender differences. ${ }^{16}$ A recent investigation in adults presented several new measurement techniques in an effort to identify the predisposing factors for elbow arthrosis. ${ }^{17}$ However, there is no information describing radiographic techniques in diagnosing and evaluating early degenerative changes such as bony impingement.

The weakness of our research is the small group study with only one orthopedic surgeon evaluating the radiographs. Thus, further research, with a larger subject group and more radiograph evaluators is needed to assess the reliability of these techniques.

\section{CONCLUSIONS}

Our study proved that measuring anterior and posterior impingement arcs on standard lateral elbow radiographs is a useful method for the easy and early diagnosis of early elbow degenerative disease. It is also useful for pre-operative planning and post-operative evaluating in symptomatic patients. With these radiographic parameters we established a firm basis for further research and for the development of a biomechanical model that can be used for computer-assisted elbow arthroscopy and even robotic operative techniques.

Table 1: Patients' characteristics

\begin{tabular}{|c|c|c|}
\hline & $\begin{array}{l}\text { Study group } \\
(\mathrm{n}=31)\end{array}$ & $\begin{array}{l}\text { Control group } \\
(\mathrm{n}=31)\end{array}$ \\
\hline Sex & 24 male, 7 female & 14 male, 17 female \\
\hline Age & $45 \pm 11$ & $37 \pm 12$ \\
\hline Dominant hand & $74 \%$ right & $71 \%$ right \\
\hline $\begin{array}{l}\text { Pathology on } \\
\text { dominant hand }\end{array}$ & $74.20 \%$ & $87.10 \%$ \\
\hline
\end{tabular}

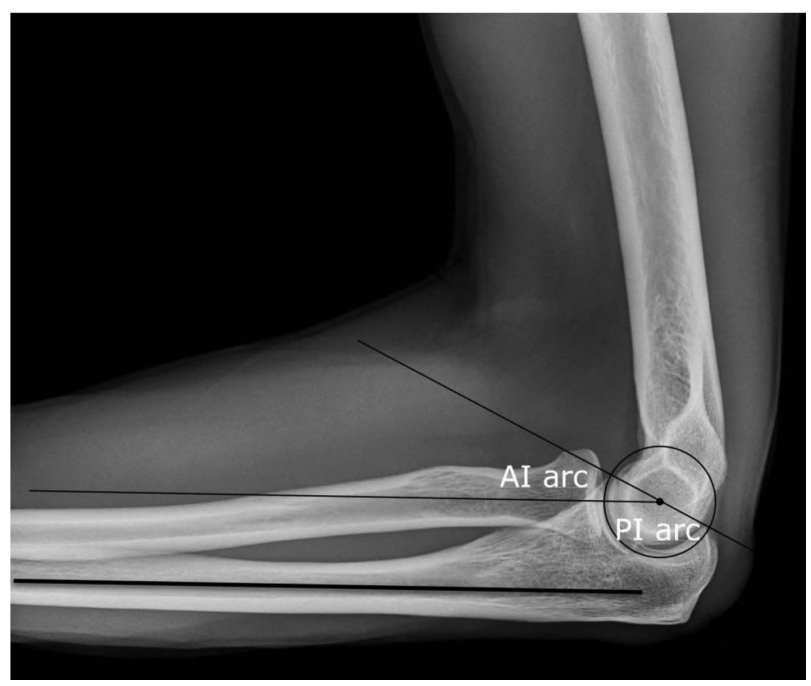

Figure 1: AI and PI arc measurement on a lateral elbow X-ray
Table 2: Elbow measurements during first evaluation (Mean \pm standard deviation (SD))

\begin{tabular}{|c|c|c|c|}
\hline & $\begin{array}{l}\text { Study group } \\
\quad(\mathrm{n}=31)\end{array}$ & $\begin{array}{l}\text { Control group } \\
\quad(\mathrm{n}=31)\end{array}$ & $\mathrm{p}$ \\
\hline Flexion & $115 \pm 8^{\circ}$ & $139 \pm 5^{\circ}$ & $<0.05$ \\
\hline Extension & $-19 \pm 12^{\circ}$ & $0 \pm 0^{\circ}$ & $<0.05$ \\
\hline ROM & $96 \pm 4^{\circ}$ & $139 \pm 5^{\circ}$ & $<0.05$ \\
\hline $\mathrm{AI}$ arc & $44 \pm 7^{\circ}$ & $20 \pm 4^{\circ}$ & $<0.05$ \\
\hline PI arc & $172 \pm 10^{\circ}$ & $150 \pm 5^{\circ}$ & $<0.05$ \\
\hline $\begin{array}{l}\text { Mayo elbow } \\
\text { score }\end{array}$ & $5 \pm 13$ & $81 \pm 9$ & $<0.05$ \\
\hline
\end{tabular}

Table 3: Elbow measurements in study group before and after operation $($ Mean $\pm \mathrm{SD})$

\begin{tabular}{|c|c|c|c|}
\hline & \multicolumn{3}{|c|}{ STUDY GROUP } \\
\hline & $\begin{array}{c}\text { Before operation } \\
(\mathrm{n}=31)\end{array}$ & $\begin{array}{c}\text { After operation } \\
(\mathrm{n}=31)\end{array}$ & $\mathrm{P}$ \\
\hline Flexion & $11 \pm 8^{\circ}$ & $131 \pm 9^{\circ}$ & $<0.05$ \\
\hline Extension & $-19 \pm 12^{\circ}$ & $-5 \pm 5^{\circ}$ & $<0.05$ \\
\hline ROM & $964^{\circ}$ & $127 \pm 9^{\circ}$ & $<0.05$ \\
\hline AI arc & $44 \pm 7^{\circ}$ & $23 \pm 5^{\circ}$ & $<0.05$ \\
\hline PI arc & $172 \pm 0^{\circ}$ & $153 \pm 7^{\circ}$ & $<0.05$ \\
\hline $\begin{array}{c}\text { Mayo elbow } \\
\text { score }\end{array}$ & $59 \pm 13$ & $78 \pm 11$ & $<0.05$ \\
\hline
\end{tabular}

\section{REFERENCES}

${ }^{1}$ D. Blonna, E. Bellato, E. Marini, M. Scelsi, F. Castoldi, Arthroscopic treatment of stiff elbow, ISRN Surg., 6 (2011) 378135, doi:10.5402/ 2011/378135

${ }^{2}$ S. Nandi, S. Maschke, P. J. Evans, J. N. Lawton, The stiff elbow, Hand (N Y)., 4 (2009), 368-379, doi:10.1007/s11552-009-9181-Z

${ }^{3} \mathrm{~V}$. Wilson, Upper extremity injuries in the throwing athlete, Mo Med., 108 (2011), 170-172

${ }^{4}$ P. D. Kim, M. W. Grafe, M. P. Rosenwasser, Elbow stiffness: etiology, treatment and results, Journal of the American Society for Surgery of the Hand, 5 (2005), 209-216, doi:10.1016/j.jassh. 2005.08.003

${ }^{5}$ J. E. Adams, L. H. Wolff 3rd, S. M. Merten, S. P. Steinmann, Osteoarthritis of the elbow: results of arthroscopic osteophyte resection and capsulectomy, J Shoulder Elbow Surg., 1 (2008), 126-131, doi:10.1016/j.jse.2007.04.005

${ }^{6}$ U. Kandemir, F. H. Fu, P. J. McMahon, Elbow injuries, Curr Opin Rheumatol., 2 (2002), 160-167

${ }^{7}$ R. A. Gallo, A. Payatakes, D. G. Sotereanos, Surgical options for the arthritic elbow, J Hand Surg Am., 5 (2008), 746-759, doi:10.1016/ j.jhsa.2007.12.022

${ }^{8}$ U. Meglič, O. Zupanc,Vprašalniki za oceno funkcije komolčnega sklepa - uporaba in prevod, Zdravniški vestnik, 2 (2012), 98-104

${ }^{9}$ D. N. Adla, D. Stanley, Primary elbow osteoarthritis: an updated review, Shoulder and Elbow, 3 (2011), 41-48

${ }^{10}$ K. P. Valkering, H. van der Hoeven, B. C. Pijnenburg, Posterolateral elbow impingement in professional boxers, Am. J. Sports Med., 2 (2008), 328-332, doi:10.1177/0363546507308937

${ }^{11} \mathrm{~S}$. Tyrdal, R. Bahr, High prevalence of elbow problems among goalkeepers in European team handball - handball goalie's elbow, Scand. J. Med. Sci. Sports., 5 (1996), 297-302

${ }^{12}$ F. S. Chen, A. S. Rokito, F. W. Jobe, Medial elbow problems in the overhead-throwing athlete, J. Am. Acad. Orthop. Surg., 2 (2001), 99-113

${ }^{13}$ C. A. Goldfarb, J. M. Patterson, M. Sutter, M. Krauss, J. A. Steffen, L. Galatz, Elbow radiographic anatomy: measurement techniques 


\section{U. MEGLIČ, O. ZUPANC: SIGNIFICANCE OF THE RADIOGRAPHIC PARAMETERS IN THE DIAGNOSIS ...}

and normative data, J Shoulder Elbow Surg., 9 (2012), 1236-1246, doi:10.1016/j.jse.2011.10.026

${ }^{14}$ A. Zarezadeh, K. Mamelson, W. C. Thomas, B. S. Schoch, T. W. Wright, J. J. King, Outcomes of distal humerus fractures: What are we measuring?, Orthop. Traumatol. Surg. Res., 8 (2018), 1253-1258, doi:10.1016/j.otsr.2018.08.017

${ }^{15}$ J. C. Cheng, K. Wing-Man, W. Y. Shen, H. Yurianto, G. Xia, J. T. Lau, A. Y. Cheung, A new look at the sequential development of elbow-ossification centers in children, J. Pediatr. Orthop., 2 (1998), $161-167$
${ }^{16}$ W. N. Keenan, J. Clegg, Variation of Baumann's angle with age, sex, and side: implications for its use in radiological monitoring of supracondylar fracture of the humerus in children, J. Pediatr. Orthop., 1 (1996), 97-98

${ }^{17}$ L. A. Rettig, H. Hastings, J. R. Feinberg, Primary osteoarthritis of the elbow: lack of radiographic evidence for morphologic predisposition, results of operative debridement at intermediate follow-up, and basis for a new radiographic classification system, J. Shoulder Elbow Surg., 1 (2008), 97-105, doi:10.1016/j.jse.2007.03.014 